\title{
めっき被覆した長寿命コーターブレード
}

\section{Long life coater blade covered with special chromium plating}

侏野村鍍金技術部 北 村 保 志

\author{
Yasushi Kitamura \\ Technical development division, Nomura Plating Co., Ltd.
}

\begin{abstract}
Some kinds of surface coating methods such as plating, thermal spraying and ion plating have been tested for prolonging life of coater blades. It is found that special chromium plating is best coating of them for wear resistance. In addition to coating methods, it is very important for coating profile to be adjusted to types of coaters.
\end{abstract}

\section{1.はじめに}

1950 年の始めに USA の Rice Berton 社がブレード コーターを開発してから約 40 年が経過している。当初 は上質コート紙のみで, 望工量も $5 \sim 7 \mathrm{~g} / \mathrm{m}^{2} /$ side が標 準であったか，その後，林種や塗工量の䇥囲が大幅に 拡大され，国内でも A 1, A 2, A 3 の紙から B 2, B 3 の紙や高級白板にまで沉用されている。これに伴い， ブレードコーター用のフレードも初期には渝入品を使 用していたようであるが現在では特殊品を除いて殆ど 国産の SK-4 やSK-5 の鑭板製である。

そして，これらの材質からなるコーターフレードの 抱える問題として短寿命であることが挙げられる。こ れは紙種, 塗工液の組成, 浱度, 粘度のみならす塗工 スピード,フレードの先端形状（ペヘルタイプあるい はベントタイプ）およびューザー僋の品質判定基準等 により異なっているか，通常 A 2 秪程度の㳂工量 16 $\sim 18 \mathrm{~g} / \mathrm{m}^{2} /$ sideでの平均寿命は 8 時間というのが一 般的なレベルようである。そして，これが何等对策 のないまま今日に至っている。

当社は 1916 年以来, 表面処理に取り組みその間に培 われた技術を基盤に 1988 年から製紙業の抱える テーマ,“コーターフレードの長寿命化”に着手し,こ の度「長寿命クロム被夏コーターフレード」を開発し た。塞用化に至るまでには，めっきの他，溶射，イオ ンプレーティンク, イオン注入など各種の表面処理法

平成 4 年度年次大会 ('92.11.11 13, 紀伊勝浦) に おいて発表した。
を検討したが, 従来のクロムめっきを改良した皮膜が 最も酎摩耗性に優れていることを見出した。ところが， 単に表面被夏材によって㓦摩耗性を改善しただけでは 実使用に耐之得ず，刃先精度とも密接な関係があるこ とが判明した。すなわち，長寿命を得るための条件と してブレード先端精度,つまりキャンパーや被言材を 含めた板厚精度の向上のみならず, コーターの型式に 見合った被覆材の被覆プロファイルが重要であること を見出した。すなわち，適正なめっき厚さとコーター ヘッドの型式に適合しためっきプロファイルとするこ とによって, 少なくとも従来品の 3 倍以上の長寿命を 得ることができた。

\section{2. クロムめつきフレード開発の経緯}

当クロムめっきブレードの開発当初から本年 $(\mathrm{H} .4$ 年) 7 月までの経稦および調查事項を要約すると次の ようである。

（1） 1988 年 8 月：当社福山工場に自社製の耐磨耗 試験機 (Abrasion Tester) を設置。

(2) 1988 年 11 月 1989 年 3 月：耐磨耗試験機を使 用して耐磨耗性のある新規フレード被夏材の検討 を開始し，当社が 1987 年に開発した R-62 と称す る新しいクロムめっきが最も耐磨耗性に優れてい ることを確認した。

(3) 1989 年 5 月 1989 年 9 月：A 社の実機におい てべントタイプューターブレートによる柽量㴻工 でそのメリットか確認された。

（4）1990年 4 月〜6月：ユーザー各社に試行品を納 入し反応を調查した。 
(1) 当初, SK 材のブレード素材に施すめっき厚 さやフレードの刃先精度との関係を実機で確認 した。その結果, 寿命はめっき厚さに比例する ことや、ユーザーによりストリークや湮りむら を生したり，従来の SK 材製ブレードの数倍に 及ぶ長寿命を示す場合もあり評価が一定しな かった。

(2) その原因追及のためブレードごとに加工ロッ トナンパーと製品ナンパーを付け，めっき厚さ と測定位置を事細かに調査してプロファイルを 描きこれをユーザーの使用結果と対比した。

(3) 使用済みのブレードの断面形状を調查し, 長 寿命のものと短寿命のものの差異を比較検討し た。

(4) 以上の様な調查結果をもとに, ユーザーの コーターヘッドに適合した適正なめっきプロ ファイルとなるようにめっき条件を繰返し修正 した。

（5） 1990 年 7 月：1 部のユーザーに対して製品納入 を開始し現在に至っている。この間のべントおよ びぺベルタプを合わせたコーターブレードの納 入実縤は合計 3,200 枚 (1990 年 7 月初 1992 年 9 月末までの 2 年 3 ヶ) である。
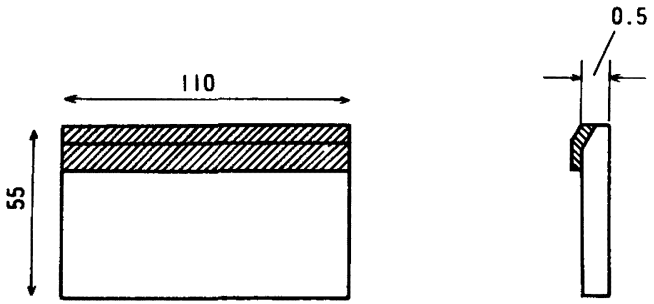

图1 テストブレードの形状と被蹰材の施工範囲
3. 長寿命コータープレードの基礎テストの概要

(1) 磨耗テストの条件

使用した塗工液：炭酸カルシウムとラテックスを主 体としたものを $4 \mathrm{l} / \mathrm{min}$. の流量 で使用した

スピード (ロール周速) $: 1,000 \mathrm{~m} / \mathrm{min}$. 一定 ブレード線圧 $: 0.8 \mathrm{~kg} / \mathrm{cm}$ とした テスト装置：自社製磨耗試験機

(2) 磨耗テストに供した試料とブレート形状

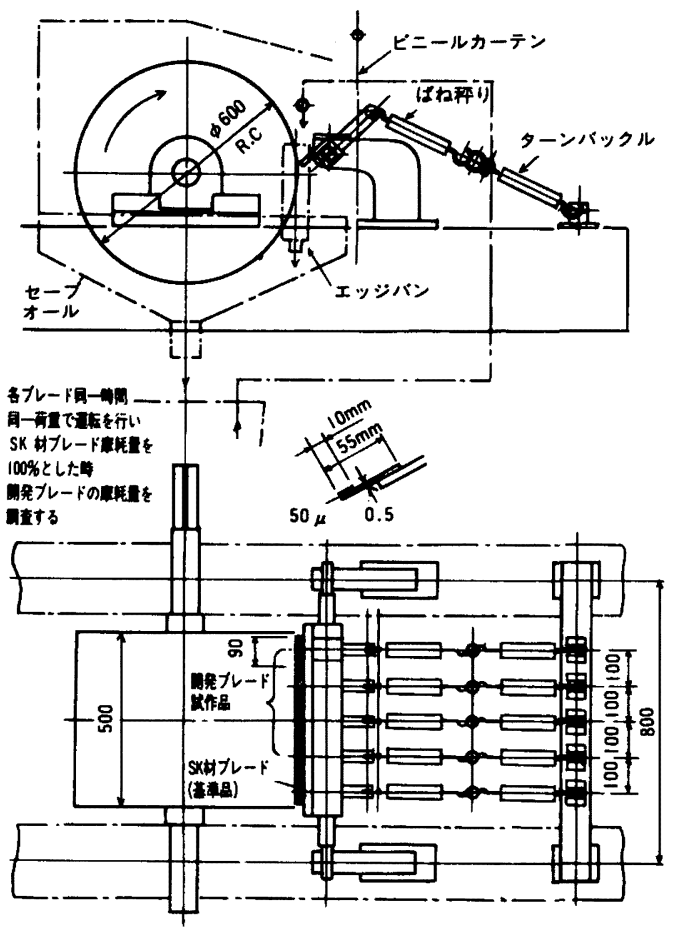

図 2 コーターフレードの磨耗テスト機の外観困

表 1 摩耗テストに供した耐摩耗性材料

\begin{tabular}{|c|c|c|c|c|c|}
\hline No. & 材 料 名 & 形成方 法 & 被䨱材厚さ & 硬 巳 (Hv) & 密度 $\left(\mathrm{g} / \mathrm{cm}^{3}\right)$ \\
\hline 1 & SK-5 (従 来 品) & 圧 延, 調 質 材 & $* 0.5 \mathrm{~mm}$ & 530 & 7.9 \\
\hline 2 & 通常の硬質クロム & 電 気めっき & $30 \mu \mathrm{m}$ & 980 & 7.1 \\
\hline 3 & 新しいクロム(R 62) & 電 気めっ & $30 \mu \mathrm{m}$ & 1,100 & 7.1 \\
\hline 4 & アルミナ・チタニア & プラズマ溶 射 & $200 \mu \mathrm{m}$ & 800 & 3.4 \\
\hline 5 & 窒化チタン (TiN) & イオンプレーティンク & $5 \mu \mathrm{m}$ & 2,800 & 5.4 \\
\hline 6 & 窒化クロム $(\mathrm{CrN})$ & イオンプレーティンク & $5 \mu \mathrm{m}$ & 2,000 & 5.8 \\
\hline
\end{tabular}

注）＊印はテストフレードの板厚である 
表 2 各種酎磨耗性材料の磨耗減量

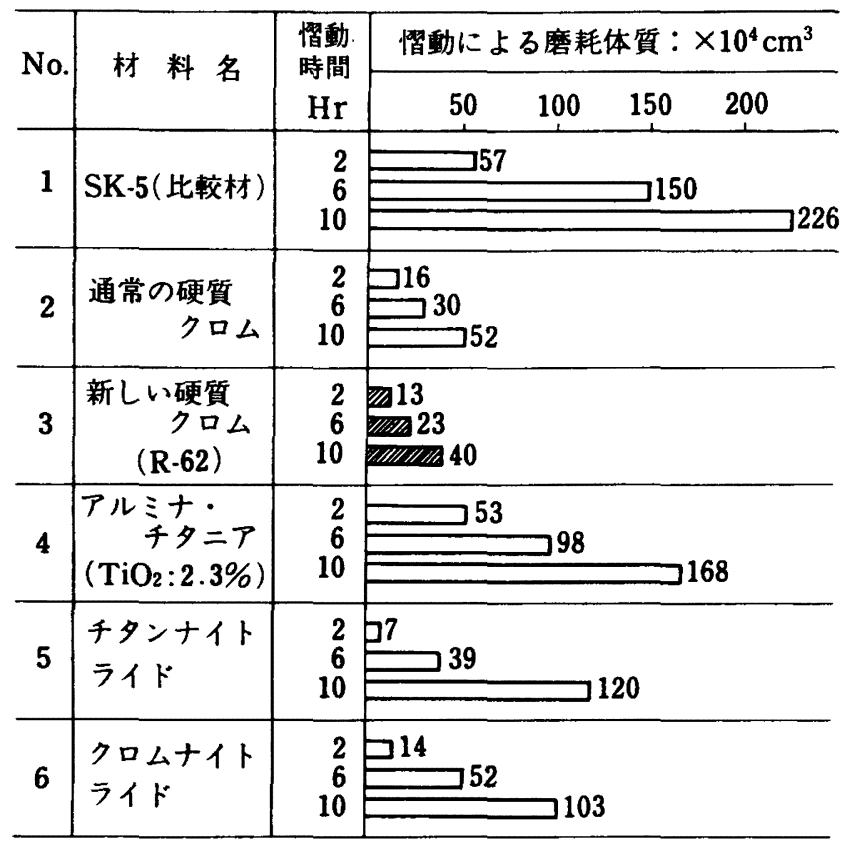

磨耗テストに供した耐磨耗性材料の代表的なものを 表1に，また図1にテストブレードの形状を示す。

(3) 評洒方法とその耛果

图 2 に示すようにコムロールに筀工液を連続して流 しながらテストフレードを一定圧力で押付け，それぞ れ 2,6,10 時間連続運転させた後の磨耗体積量により 酎磨耗性を評洒した。表 2 にその結果を示す。 チタンナイトライト，クロムナイトライドの初期耐 磨耗性はクロムめっきと同等以上である。しかしなが ら，イオンプレーティンクによる聇磨耗被膜の形成は 一般的に言って数ミクロンが限度と言っても良く，こ の意味ではいかに酎磨耗性の優れた被膜であっても， ある程度の被膜厚みがなければコーターフレードの的 磨耗性改善には使用出来ないことが分かる。

以上のような結果に基つき，新しい硬質クロムめっ き被膜を長寿命コーターフレードの被膜に採用するこ ととした。その寿命は従来の SK 材のフレードの 4 7 倍であった。

\section{4. 新クロムめっき被膜ブレードの実機への適用}

\section{1 実機で発生した問題点とその解明}

新クロム被膜フレードを実際にコーターに適用して： みると, 従来の SK 材のフレードと比へて 3 倍以上の 長寿命を示すものがあるかと思えば，また，染工ムラ (ストリークやピーディンクを含む) を生しるものも
あって，ユーザーにとって必ずしも満足できる状態で はなかった。この原因を明らかにするため，使用前後 のブレードについて下記項目を詳細に追跡調查した。

(1) ベント, ベべルの各タイプについての一般的 な磨耗傾向

(2) 被覆したクロムの平均厚さ $(\chi)$, 標準偏差

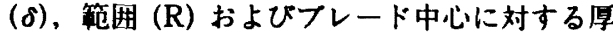
みプロファイルの FR (操作側)，BK (駆動側) の对称性

(3) 標隼偏差 $(\delta)$ と染工品質の関係

(4) クロム厚さとフレードの寿命の関係

(5) クロム被覆厚さの長手方向のプロファイルと 染工品復の関係

その結果明らかになってきたことを以下，順次説明 する。

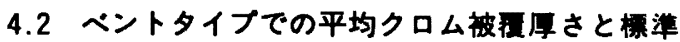

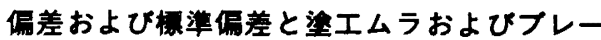
ト然命の閶係

数百枚に及ぶフレードの実測俌より図 3 に示すよう な関係が得られた。

図 3 左のクラフはクロムめっき平均被夏厚さとその 標隼偏差值，および寿命延長倍率を表している。被顠 厚さが增加するに従って標隼偏差值は大きくなる傾向 があり，クロムめっき厚さの增加は寿命延長につなが るが、一方ではユーザーの使用可否判定基準が存在し， 


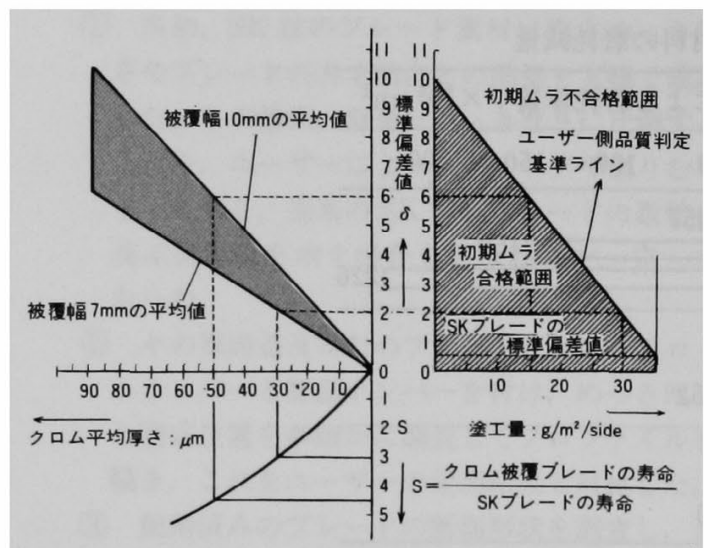

図 3 ベントブレードのクロム被覆厚さとその標準 偏差および堻工ムラ, 寿命を示す関係困

ユーザーのコーターで必要とされる塗工量とクロム被 膜厚の標準偏差値が密接に関連する。すなわち,クロ 么被覆厚さをかりに $50 \mu \mathrm{m}$ とすると, その標準偏差値 は平均 $6 \mu \mathrm{m}$ 程度となるので, 推奖染工量は $15 \mathrm{~g} / \mathrm{m}^{2} /$ side までと言うことになる。なお，図3のデー夕はす べてクロム被覆（めっき）したままのものであって， あらゆる染工量に対応するには標準偏差値を小さくす れば良いことになるが，その手段の1つとして，例え ばクラインタ研磨することが挙げられる。しかし，ク ラインタ研磨するとコストアップにつながるだけでな く、ブレードのタイプ (ベベル) によっては別の弊害 が出てくることが分かった。この事については後で触 れたい。

4.3 ペベルタイプでのパッキングロールのたわみ 二次曲線とクロム被膜厚みのプロファイルと の関係

当初, 同一ユーザーに同一ロットのフレート゚を納入 しても，長寿命のものや㳣工ムラを生して全く使用に 耐之得ないものが発生することは既に述べたとおりで ある。これらを詳細に調查して見ると必ずしもクロム めっき被覆厚の標準偏差值だけが塗工ムラの原因と なっていないことが分った。即ち，一枚のブレードに おいてクロム被覆厚の標準偏差值が大きいものでも長 時間ムラのない塗工が出来たものもあり,この様なブ レードは先端形状がロールで言うところのクラウン状 態となっていることが判明した。考えられるその理由 を参考例 1) 〜5) に示す。

従って，このたわみ現象をコーターブレードのパッ キンクロールに当てはめても同じ理屈がなりたち（図 4 参照), フレードのキャンバーがストレートであれ ばハハッキンクロールの作る上向きのたわみ二次曲線

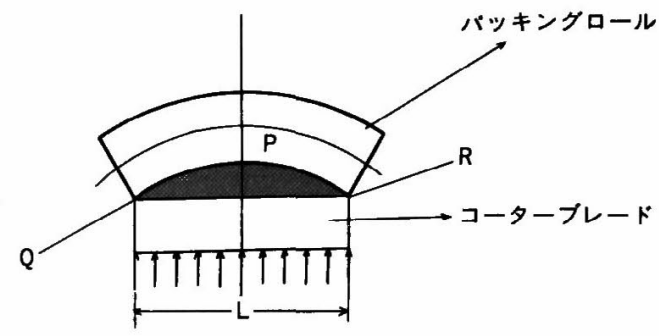

图４コーターブレードとバッキンクロロールの関係

(Q-P-R のライン) に沿わないことになる。

即ち,ブレードの先端部分が紙を介してバッキンク ロールを加圧するべへルタイプのブレードではべント タイプ程ではないか，先端がストレートではなくパッ キングロールを加圧した時に生ずる上向きのたわみ二 次曲線に合った形状が良いことになる。また，従来の SK 材ブレードのキャンバーがストレートの状態で あっても，それ程問題が無かったのは，もともと素材 の硬さが低く磨耗しやすいために，すぐさまバッキン クロールになじんでしまうためと考えられる。ところ が, 当社の開発したクロム被覆ブレードの場合では, 耐磨耗性の良いことが逆に災いして, 磨減し難いため に初期ムラが長時間持続することになる。また，ク口 么厚の標準偏差伹が大きい場合でも，厚みのプロファ イルがバッキンクロールの上向きのたわみ二次曲線に 順応していれば，初期ムラがなく長時間使用できるブ レードとなる。寿命延長のためにクロムを厚く被覆す ると厚みの標準偏差値が大きくなり，あらゆる塗工量 に对応できなくなるが，その対応策としてクラインダ 研磨することを先に述べた。このようにして，標準偏 差值を小さくし, 且つブレードの取付け位置を正常に 出来れば塗工ムラを生じ難いブレードとなるが，スト レートキャンバーの状態に研磨加工してしまうために, バッキンクロールのたわみには順応しなくなるので, ロールの撓み二次曲線に順応するまで, 初期塗工ムラ による損紙を大量に発生することになる。その間ブ レードの両端近傍は無為に磨耗する為, 寿命が短くな るのはさけ難い。

5. まと め

今迄の説明を要約して取りまとめると表了のように なる。なお，表中のA型，B型は図 5 の状態を，また ブレードの “正常取付”, “不正常取付”とは图 6 の状 態をさす。

以上のように, 当社の新しいクロム $(\mathrm{R}-62)$ を被覆 して，厚みプロファイルを適切に整えたコータープ 


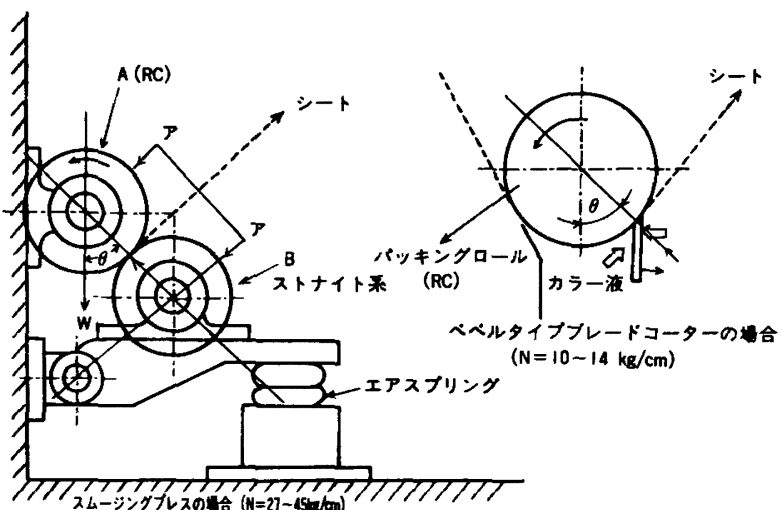

1) 昰作したロール

3）ロールを加任した时

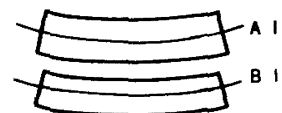

2）ロールをマシーンにセットした时
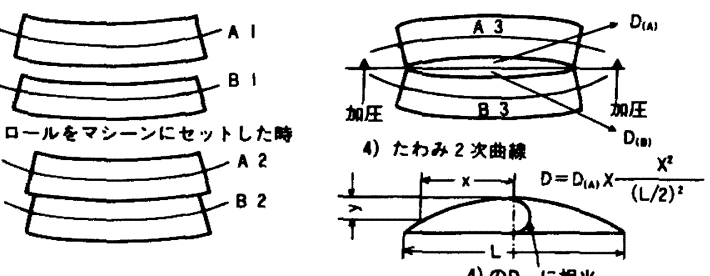

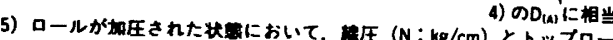
D mma同保次式で示される。
$P=\{(N \times)-$ mass $\}$
P:トップールヘの些

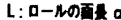

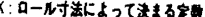
$D_{w}=k \times \frac{P}{E \times 1}$
E: $0-10+0$ )

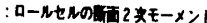

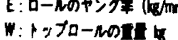
(hamm)

[参考例］製柢檴のスムージンクプレスのクラウン合わせ を参考としたバッキンクロールとブレードの関係

初期選択磨耗部分

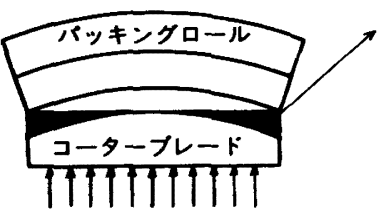

A资（鿷したストレートフレード）

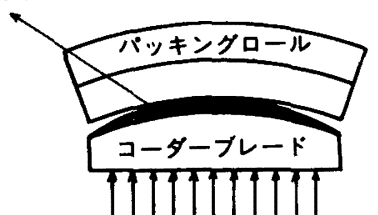

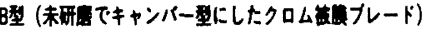

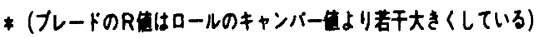

图 5 バッキンクロールに对するストレートフレードとオープン キャンバーフレードの当りを示す図

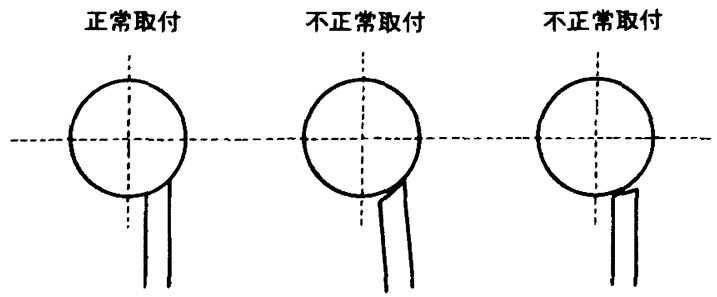

图 6 ブレードの取付け事例 


北村保志

表 3 ブレードの比較

\begin{tabular}{|c|c|c|c|c|c|c|}
\hline 種 & 図5の & フレードの & フレードのロールに & 初期なじみ & 平 均 & 操業 性 \\
\hline 性 & 分 類 & 取付状態 & 对するなじみ性 & 時 & 寿 命 & 珠 来 \\
\hline \multirow{2}{*}{$\begin{array}{l}\text { 従来の被品なし } \\
\text { SK 材ブレード }\end{array}$} & \multirow[b]{2}{*}{ A 型 } & 正常取付 & 問題なし & $\mathrm{T}$ & S & 準 \\
\hline & & 不正常取付 & $\begin{array}{l}\text { 硬度が高くないので問 } \\
\text { 題なし }\end{array}$ & $\mathrm{T}$ & $\mathrm{S}$ & 標 \\
\hline \multirow{2}{*}{$\begin{array}{l}\text { クロムやセラミッ } \\
\text { クを被覆した高硬 } \\
\text { 度フレードを研磨 } \\
\text { したもの }\end{array}$} & \multirow[b]{2}{*}{ A 型 } & 正常取付 & $\begin{array}{l}\text { 取付精度が確実であれ } \\
\text { ば問題なし }\end{array}$ & $3 \sim 4 \mathrm{~T}$ & $5 \sim 7 \mathrm{~S}$ & SKより悪い \\
\hline & & 不正常取付 & $\begin{array}{l}\text { 高硬度で耐摩耗性が } \\
\text { アップした分だけ，ム } \\
\text { ラ、ストリークが発生 } \\
\text { し易い }\end{array}$ & $\begin{array}{l}3 \sim 4 \mathrm{~T} \\
\text { 以 上 }\end{array}$ & - & - \\
\hline $\begin{array}{l}\text { 未研磨クロム被夏 } \\
\text { キャンバーフレー } \\
\text { ド }\end{array}$ & B 型 & $\begin{array}{l}\text { 正常, 不正常の } \\
\text { 差があまり問題 } \\
\text { にならない }\end{array}$ & $\begin{array}{l}\text { 面長, 断面方向とも中 } \\
\text { 心から而端へ広がるよ } \\
\text { うに, 自然になじむ }\end{array}$ & $\begin{array}{l}\text { Tより } \\
\text { 短時間 }\end{array}$ & $4 \sim 6 \mathrm{~S}$ & $\begin{array}{l}\mathrm{SK} \text { フレード } \\
\text { よりも操業性 } \\
\text { が良い }\end{array}$ \\
\hline
\end{tabular}

レードは従来の SK 材の 3 倍以上の長寿命を示すこと が明らかとなっており，当ブレードを使用されている ユーザーの声として，長寿命であることによってフ レード交换頻度の減少による操業性の改善，ロール人 のブレードのなじみ時間の短縮およびフレードを交換 する度に生しる損林の量が低減した。或いは，硬度の
高いもので塗工するので紙質が改善されたとも聞いて いる。この成果に満足せずューザーと一体となってど の様な鿾工紙種やマシーン幅にも適用できるよう一首 の品質改善と，量産化対策によるコストタウンに取組 んで行く所存である。 